\title{
ARTYKUtY
}

Klio. Czasopismo poświęcone dziejom Polski i powszechnym PL ISSN 1643-8191, t. 53 (2)/2020, s. 3-18

(c) $\odot$

JaKub WęGLORZ*

\section{Naukowy wymiar nowożytnych teorii medycznych i ich postrzeganie przez pryzmat racjonalności badacza jako problem poznawczy}

\author{
A scientific dimension of astrology and a theory \\ of signatures and sympathy in early modern treatment
}

Streszczenie: Doktryna humoralna nie stanowiła w pełni jednolitej i spójnej teorii. Składała się z wielu elementów i poglądów, z których znaczna część została zweryfikowana jako błędna. Skokowy rozwój medycyny, który nastąpił w XIX w., oraz gwałtowny rozkwit nauki w ciągu ostatnich dwóch stuleci pozwoliły na obalenie wielu założeń i twierdzeń będących podstawą założeń humoralizmu. Nieprzystawalność niektórych z nich do aktualnego paradygmatu naukowego sprawiła, że obecnie są często postrzegane nie jako element dawnej wiedzy, a raczej jako przejaw działań i poglądów o charakterze magicznym. Percepcja takich elementów dawnej nauki, jak astrologia czy teorie sygnatur i sympatyczności, przez pryzmat magii utrudniają właściwe zrozumienie ówczesnego lecznictwa

Zakład Historii Polski i Powszechnej XVI-XVIII w., Instytut Historyczny Uniwersytetu Wrocławskiego, ul. Szewska 49, 50-139 Wrocław, jakub.weglorz@uni.wroc.pl, ORCID: 0000-0002-1186-5777. 
i stwarzają mylne wrażenie odnośnie do jego charakteru. Artykuł przedstawia ten aspekt badań nad dawną medycyną jako potencjalną przeszkodę badawczą i interpretacyjną.

\begin{abstract}
A doctrine of humors was not a coherent and uniform theory. It consisted of various elements and views, most of which currently are considered as incorrect. Significant change and development of medicine in the $19^{\text {th }}$ century, as well as intensive development of science within last two centuries allowed to falsify many assumptions and hypothesis presented as basics of the doctrine of humors. As they are not compatible with a current scientific paradigm, they are considered not as an element of former, past knowledge, but as a part of magical thinking and magical practices. Perception of following elements of past scientific discipline: astrology, theory of signatures, and sympathy as melted with magic hinders proper understanding of a past treatment procedures. The paper discusses this issue, considering the perception as a probable obstacle in research and interpretation of the past.
\end{abstract}

Słowa kluczowe: teorie medyczne, historia medycyny, historia nauki, epoka nowożytna, religia, racjonalizm

Keywords: medical theories, history of medicine, history of science, early modern period, religion, rationalism

Tstnieje wiele definicji nauki - o ściślejszym lub szerszym charakterze ${ }^{1}$. Unikając zbędnych rozważań teoretycznych dotyczących pojęcia nauki i jej granic, wystarczy powołać się na społecznie akceptowany sposób postrzegania. Nauka ma opisywać jak najdokładniej rzeczywistość otaczającą człowieka za pomocą przyjętych i ustalonych metod oraz języka. Teorie formułowane przez naukę powinny być uzasadnione w zgodzie z przyjętymi metodami i podlegać weryfikacji przez zestawienie ich z wynikami obserwacji. W oczywisty sposób nauka zmienia się i ewoluuje, tak samo jak metody, którymi się posługuje. Stałym problemem, występującym na styku współczesnej nauki i dawnych metod poznawczych, jest nieprzystawalność rozwiązań stosowanych w odległej przeszłości do obecnej metodyki badania i sposobu tłumaczenia świata. Nauka, która ma - z definicji - w najlepszy możliwy sposób opisywać rzeczywistość, nie zakłada możliwości

${ }^{1}$ Historia nauki polskiej, t. 1, red. P. Suchodolski, Warszawa 1970. 
funkcjonowania innych sposobów naukowego postrzegania świata, opartych na odmiennej racjonalności. Gdy nie poddają się one współczesnej nam racjonalności, są często traktowane jako nienaukowe czy nawet magiczne.

Problem ten, który często występuje w publikacjach z zakresu historii lecznictwa, chciałbym naświetlić na podstawie materiału źródłowego w postaci staropolskiej korespondencji, pamiętników oraz druków poradnikarskich od XVI do XVIII w. ${ }^{2}$ Rozważania prowadzone w niniejszym artykule, dotyczące postrzegania leków i metod terapii wykorzystywanych przez dawną medycynę, odnoszą się jedynie do medycyny naukowej, nazywanej też często uniwersytecką. Jej wpływ i stosowanie rozciągały się daleko poza działania podejmowane przez absolwentów wyższych uczelni. Zgodnie z głoszonym przez naukę sposobem interpretowania spraw zdrowia i choroby szkoleni byli także przedstawiciele zawodów cechowych parających się leczeniem. Z podręczników i poradników medycznych korzystała również znaczna grupa empiryków, nieposiadających formalnego wykształcenia (czasem bezprawnie pretendujących do miana „doktora”), ale leczących zgodnie ze zdobytą wiedzą - opartą na ówczesnych standardach naukowych ${ }^{3}$. Funkcjonujące przez cały okres nowożytny lecznictwo ludowe praktykowane przez znachorów, guślarzy i wiejskie zielarki, choć dotyczyło ogromnej części społeczeństwa, nie jest przedmiotem dociekań podejmowanych w tym artykule. Mimo że nie pozostawało ono całkowicie poza wpływem nowożytnej nauki, opierało się na odmiennym postrzeganiu zasad rządzących zdrowiem i chorobą.

Nauka oraz medycyna epoki nowożytnej w zasadniczych kwestiach zdecydowanie odżegnywały się od stosowania zabiegów magicznych i czarów, choć przez znaczną część omawianego okresu nie doszło do ich jednoznacznego zanegowania jako czynnika sprawczego. Zarówno nauka, jak

2 Tekst prezentuje rezultaty badań finansowanych z grantu Narodowego Centrum Nauki 2017/26/E/HS3/00452.

3 Sprawy podejścia do formalnych uprawnień do leczenia porusza artykuł: J. Węglorz, Znaczenie i postrzeganie kwalifikacji do uprawiania sztuki lekarskiej w Rzeczypospolitej, $\mathrm{w}$ : „Sapientia ars vivendi putanda est”: wokót kultury i polityki: studia z dziejów nowożytnych ofiarowane Profesorowi Marianowi Chachajowi, red. A. Perłakowski, B. Rok, F. Wolański, Kraków 2019, s. 47-60. 
i religia do XVIII w. nie kwestionowały istnienia sił nadprzyrodzonych, a pośrednio nawet potwierdzały ich realną moc, ostrzegając przed potencjalnymi konsekwencjami. W XVI i XVII stuleciu stosunkowo rozpowszechniony był pogląd o możliwości magicznego sprowadzenia choroby lub wywołania w ten sposób czyjejś śmierci. Przez cały okres nowożytny działania magiczne i praktyki czarnoksięskie pozostawały poza zakresem oficjalnych zainteresowań nauki, religia surowo zakazywała zaś parania się czarami, będącymi domeną diabła i demonów. Wobec działań magicznych zalecane przez Bazylego Rudomicza (lekarza i uczonego) środki zaradcze powinny opierać się na egzorcyzmach i modlitwie: „[...] z powodu zawistnej złośliwości ktoś już kilka razy potajemnie podrzucił nam znaki zaczarowane, np. przedtem pieska sztucznie zrobionego, różne ziela itd., a ostatnio Sobek znalazł w bramie naszej kamienicy związane pazury. Ale my ufając naszemu Bogu, jego opiece poruczamy siebie i całe nasze mienie. On niech nas broni i wspiera!"’ . Jan Antoni Chrapowicki w obliczu czarów stwierdził zaś: „[...] naleziono załom, to jest czary w życie dworskim łabieńskim od Tryczów i w dołek wkopany kłosami żyto wetknione, i powiązane w kilku miejscach; nie tykano się, ale ożęto wkoło, a to zostawiono. [...] Ksiądz franciszkanin przyjechał z Grodna, po mszy świętej odprawił egzorcyzm u tego załomu, który zakopawszy, kamieniami zawalono oraz i we dworze wszędzie egzorcyzmy czytał"'.

Wiara w możliwość magicznego sprowadzenia choroby stopniowo zanikała w dyskursie naukowym w ciągu XVIII stulecia. W poradnikach medycznych powstających w tym okresie ${ }^{6}$ właściwie nie występowały już informacje o możliwości wywołania choroby przez zabiegi magiczne, nie

4 B. Rudomicz, Efemeros, czyli Diariusz prywatny pisany $w$ Zamościu w latach 1656-1672, cz. 2: 1664-1672, tłum. W. Froch, oprac. M. L. Klementowski, W. Froch, Lublin 2002, s. 131.

5 J. A. Chrapowicki, Diariusz. Część druga: lata 1665-1669, oprac. A. Rachuba, T. Wasilewski, Warszawa 1988, s. 52, 65.

6 Mowa tu o pracach tworzonych w XVIII w., ponieważ liczne przedruki utworów powstałych w poprzednich stuleciach przeważnie zachowywały dawny charakter i podejście do kwestii zjawisk metafizycznych. 
podkreślano też woli boskiej jako siły sprawczej niedomagań7. Również piśmiennictwo religijne zmieniało w tym czasie podejście do zagadnień takich jak np. nadprzyrodzone właściwości kamieni szlachetnych. Zamiast potępienia czarnoksięskiego charakteru tego rodzaju mocy podkreślało się ich naturalną genezę - natura miała posiadać pewne niezwykłe właściwości, będące darem od Boga, a nie efektem czarów ${ }^{8}$. Zanegowanie przez naukę i religię sprawczej mocy magii nie spowodowało jednak automatycznie zaniku wiary w siły nadprzyrodzone wśród ludzi. Nie doprowadziło też do zrezygnowania ze stosowania metod leczenia odwołujących się do zjawisk metafizycznych. Lecznictwo o charakterze magicznym było stosowane przez cały okres nowożytny, a i sami medycy oraz cyrulicy nie byli z pewnością wolni od wiary w magię. Czarostwo nie było jednak przedmiotem studiów i badań uniwersyteckich, a metody leczenia proponowane przez medycynę oficjalną opierały się na podstawach naukowych. Recepty i zalecenia o charakterze na wpół magicznym czy rytuały wywodzące się z ludowych przesądów bez wątpienia także były wykorzystywane - źródła wskazują, że nawet przez elity intelektualne oraz przedstawicieli medycyny oficjalnej. Dobrym przykładem takiego podejścia była postać Bazylego Rudomicza, lekarza i wieloletniego rektora Akademii Zamojskiej. Choć był uczonym i posiadał rozległą wiedzę o medycynie, to nie odrzucał wiary w magię i czary, których zgodnie z jego słowami nie należy ignorować: „[...] nasza chrześcijańska wiara zakazuje wierzyć w dni egipskie, za które niektórzy matematycy uważają okres od 16 do 18 marca włącznie, to jednak, jak widzę, nie należy ich lekceważyć" " Trudno jednoznacznie określić skalę stosowania metod nieoficjalnych i nieuznawanych przez ówczesną naukę, gdyż tego rodzaju sytuacje są trudno uchwytne źródłowo. Analiza kuracji zalecanych przez nowożytnych lekarzy wskazuje jednak, że większość podejmowanych działań terapeutycznych miała charakter naukowy, zgodny z ówczesnym sta-

7 B. Rok, Zagadnienie śmierci w kulturze Rzeczypospolitej czasów saskich, Wrocław 1991, s. 85.

8 T. Bieńkowski, Polscy przedstawiciele „scientia curiosa”, „Rozprawy z Dziejów Oświaty" 1987, t. 30, s. 17.

9 B. Rudomicz, Efemeros, czyli Diariusz prywatny pisany w Zamościu w latach 1656 -1672, cz. 1: 1656-1664, tłum. W. Froch, oprac. M. L. Klementowski, W. Froch, Lublin 2002, s. 253. 
nem wiedzy. Występujące wówczas zachowania o charakterze zabobonnym czy poglądy magiczne bez wątpienia były udziałem zarówno prostych ludzi, jak i elit intelektualnych - podobnie jak to się dzieje w dzisiejszych czasach. Otwarte pozostaje pytanie, w jakim stopniu ulegano przesądom i na ile poważnie podchodzono do tego rodzaju praktyk wśród różnych grup społecznych. Z punktu widzenia współczesnego badacza niektóre elementy stosowanych terapii mogą być trudne do jednoznacznego zakwalifikowania jako ludowe, magiczne czy uniwersyteckie ${ }^{10}$. Prowadzone w tym artykule rozważania nie mają jednak na celu wskazania granicy między medycyną uniwersytecką a ludową czy lecznictwem magicznym. Ich przedmiotem jest medycyna oficjalna w tym obszarze, w którym prezentowała działania terapeutyczne, będące efektem pojmowania świata zgodnie z zasadami ówczesnej nauki medycznej i praktyk leczniczych. W owym czasie były one kwalifikowane jako jednoznacznie naukowe.

Analizowane metody leczenia i poglądy dotyczące przyczyn chorób oraz mechanizmu działania leków wynikały z dominującej ówcześnie doktryny medycznej i opierały się na osiągniętym stanie wiedzy. Jeśli ich naukowość nie była wówczas kwestionowana, badacze przeszłości powinni oceniać racjonalność i naukowość stosowanych praktyk medycznych przez pryzmat nowożytnej nauki i jej wartości. Stanowisko takie, choć będące w zgodzie ze standardem badań historiograficznych (zasadność działań prezentowanych przez źródło historyczne wartościuje się przez pryzmat wiedzy dostępnej dla tego źródła), nie zawsze jest respektowane przez badaczy dawnej zdrowotności. Konflikt między językiem i racjonalnością źródła a ich oceną - wyrażaną przez badacza - szczególnie wyraźnie widać właśnie w przypadku badań nad przeszłością nauk medycznych. Historiografia medycyny często bardzo krytycznie odnosi się do dawnych koncepcji terapeutycznych, uznając je za nieracjonalne i niezgodne z obowiązującym dziś paradygmatem naukowym. Podejście takie wynika w dużej mierze

10 Pozostaje kwestią otwartą, na ile rozróżnienie takie było wyraźne dla chorych korzystających z pomocy lekarza i znachora. Prowadzone przez autora badania nad postrzeganiem medycyny i oczekiwaniami wobec terapii wskazują, że podziały tego rodzaju nie musiały być wcale jednoznaczne i kategoryczne z punktu widzenia pacjenta; por. J. Węglorz, Zdrowie, choroba i lecznictwo w spoteczeństwie Rzeczypospolitej XVI-XVIII wieku, Toruń 2015, s. 208-260. 
ze specyfiki tej historiografii, zdominowanej w XX w. przez paradygmat biomedyczny i nastawionej na uzasadnianie obowiązującego ideału wiedzy medycznej ${ }^{11}$.

Postrzeganie lecznictwa w przeszłości przez pryzmat realnej skuteczności terapii i efektywności leku jest jak najbardziej uzasadnione i potrzebne. Wymaga jednak odnoszenia analizowanych metod leczenia do obecnego stanu wiedzy i oceny jedynie tego, czy dana praktyka mogła skutecznie pomagać. Nie jest istotne, czy współcześnie jest uważana za magiczną lub zabobonną. Wiara w leczniczą moc radiacji i stosowanie naświetlania radem kosmetyków oraz produktów spożywczych ${ }^{12}$, które przez dzisiejszą naukę są odrzucane jako nieskuteczne, a nawet niebezpieczne, były tak samo „racjonalne” jak pogląd dotyczący wpływu komet na rozprzestrzenianie się chorób zakaźnych. W czasie, gdy przekonania te były podzielane, uchodziły za naukowe i uzasadnione, choć są podobnie bezwartościowe w ocenie dzisiejszej nauki. Używanie wartościującej kategoryzacji „racjonalności” w odniesieniu do nieskutecznych (lub nawet szkodliwych) praktyk medycznych, które opierają się na oglądzie świata odpowiadającym naszemu, przy jednoczesnym etykietowaniu „nieracjonalnością” działań terapeutycznych, co do których dzisiejsza nauka nie znajduje zrozumienia, jest niekonsekwentne i w istocie nieracjonalne.

Deprecjonowanie dawnej nauki i hiperkrytyczna ocena praktyk opartych na niestosowanych już założeniach naukowych stanowi swoistą specyfikę badań nad przeszłością nauk medycznych. Wydaje się, że wynika to $\mathrm{z}$ istoty tych nauk, skupionych na podstawowym założeniu, jakim jest efektywne przywracanie zdrowia pacjenta. Dominacja evidence based medicine w dyskursie nauk o zdrowiu jest niewątpliwie atutem, gdy dotyczy aktualnych metod terapii. Powoduje to jednak, że rozważania teoretyczne i koncepcje - niedające się jednoznacznie zweryfikować przez badania kliniczne - są traktowane nie tylko z lekceważeniem, ale nawet

11 J. Jeszke, Znaczenie polskiej historiografii medycznej dla medycyny i historii, w: Przetomy w historii. XVI Powszechny Zjazd Historyków Polskich, Wroctaw 15-18 września 1999 roku, t. 3, cz. 4, Wrocław 1999, s. 175-177.

12 T. Król, Kosmetyki radioaktywne, „Polish Journal of Cosmetology” 2017, t. 20, nr 1, s. 39-42. 
z wrogością. Próby prowadzenia badań naukowych nad homeopatią czy medycyną ajurwedyjską przez środowiska medyczne były nieraz traktowane jako działalność szkodliwa, podważająca autorytet medycyny uniwersyteckiej $^{13}$. Postawa taka wydaje się obecnie w odwrocie, o czym mogą świadczyć coraz liczniejsze publikacje z pogranicza obszaru wiedzy akceptowanej i uznawanej przez współczesną medycynę za racjonalną i klinicznie sprawdzalną. Podobny problem pojawia się przy próbach prowadzenia rozważań na temat dawnych metod leczenia, odbiegających w swych założeniach od dzisiejszej nauki. Jeśli autor nie próbuje odnaleźć w nich śladów dzisiejszej „racjonalności”, są one traktowane - w najlepszym razie - jako niepotrzebne, a czasem szkodliwe. Dlatego ważne jest podkreślenie, że w badaniach nad dawnymi metodami terapii nie chodzi o krytykę lecznictwa w obecnej formie, ani też o kreowanie kontrpropozycji dla medycyny uniwersyteckiej. Analizowanie stosowanych w przeszłości koncepcji leczenia i szukanie $\mathrm{w}$ nich zakotwiczenia $\mathrm{w}$ mierzalnych zjawiskach przyrodniczych stanowi przede wszystkim próbę lepszego poznania przeszłości. Jeśli nawet takie badania wskażą na potencjał terapeutyczny pewnych działań podejmowanych w przeszłości (niezależnie, czy były zgodne z dzisiejszym standardem leczenia), to tego rodzaju informacja powinna stanowić przede wszystkim bodziec dla przedstawicieli nauk biomedycznych - do podjęcia pogłębionych badań w tym kierunku.

Odrzucanie dawnych metod leczenia jako „nieracjonalnych”, zgodnie z aktualnie obowiązującymi normami, a przez to kwalifikowanie ich jako magicznych i niewartych analizy, jest błędem wynikającym czasem z anachronicznego oraz niekonsekwentnego myślenia historyków i antropologów kulturowych zajmujących się dawną zdrowotnością. O ile w zasadzie nie neguje się samego istnienia w epoce nowożytnej rzetelnej nauki - badającej świat zgodnie z najlepszymi dostępnymi środkami i interpretującej obserwowane zjawiska na podstawie dostępnej wiedzy - o tyle już egzemplifikacja poszczególnych poglądów m.in. stosowanych metod leczenia wynikających z owej nauki budzi często instynktowny opór badaczy. Tego rodzaju podejście, opierające się na pozametodologicznym „wyczuciu” i poszukiwaniu fragmentów racjonalności uznawanej dziś za jedyną słuszną

13 Ibidem. 
oraz prawidłowo opisującą rzeczywistość stanowi problem podejmowany już od kilku dekad przez historyków nauki ${ }^{14}$. W epoce nowożytnej w większości sytuacji przedstawiciele oficjalnego nurtu medycyny (nazywanego medycyną uniwersytecka), czyli medycy, cyrulicy (w tym inni rzemieślnicy zajmujący się medycyną zabiegowa) i aptekarze, w codziennej praktyce posługiwali się metodami zgodnymi z ówczesnym stanem wiedzy. Należy podkreślić, że pojawiające się spory o zasadność podjętej terapii opierały się na zarzutach o nieuczciwej konkurencji lub błędnym rozpoznaniu i zastosowaniu nieodpowiednich $\mathrm{w}$ danej sytuacji środków, a nie dotyczyły kwestii ewentualnej nienaukowości czy magicznego charakteru podjętych działań leczniczych ${ }^{15}$. Jeśli nawet zarzuty o sprzeniewierzenie się nauce medycznej pojawiały się w omawianej epoce, musiały być rzadkie, ponieważ są słabo udokumentowane źródłowo. Mimo to obecność w podejmowanych działaniach terapeutycznych elementów astrologii, teorii sygnatur czy teorii sympatyczności bardzo często wiąże się dziś z automatycznym zaszeregowaniem danej wiedzy jako nieracjonalnej, a nawet mającej charakter magiczny. Tego rodzaju podejście utrudnia prawidłowe rozpoznanie zjawiska i zaciemnia obraz dawnej medycyny, w znacznym stopniu spychając ją w stronę lecznictwa ludowego i odbierając jej atut naukowości.

Jednym z czołowych przykładów wpływu współczesnej badaczom racjonalności na ocenę statusu naukowego analizowanych poglądów medycznych jest astrologia. Do XVIII w. była ona traktowana jako dyscyplina naukowa, a diagnostyka medyczna wprost wymagała uwzględnienia uwarunkowań astrologicznych. W ciągu XVIII stulecia medycyna uniwersytecka wycofała się z części poglądów dotyczących wpływu zjawisk astralnych na stan zdrowia człowieka. Warto jednak zauważyć, że dystansowano się

14 Zob. J. Jeszke, Historyk i lekarz jako badacz dziejów nauk medycznych, „Medycyna Nowożytna. Studia nad historią medycyny" 1997, t. 4, z. 1/2, s. 70-72.

15 K. Pękacka-Falkowska, Spory kompetencyjne między taziebnikami i chirurgami toruńskimi w XVIII w. Przypadek Johanna Zandera, „Medycyna Nowożytna” 2015, t. 21, z. 2, s. 137-171; J. Węglorz, Wspótpraca interdyscyplinarna i wprowadzenie podstaw metodologicznych oraz warsztatowych jako konieczność $w$ badaniach nad historia medycyny, "Czasy Nowożytne" 2017, t. 30, s. 235-236. 
głównie od wiary we wpływ zaćmień czy komet ${ }^{16}$, całkowite zdezawuowanie wpływu gwiazd na uwarunkowania zdrowotne nastąpił natomiast dopiero wraz z upadkiem patologii humoralnej jako doktryny medycznej. Przez cały okres nowożytny medycyna głosiła pogląd o istniejących powiązaniach między człowiekiem a kosmosem (w rozumieniu ciał niebieskich), który miał wpływać na funkcjonowanie organizmu. Poglądy takie wynikały wprost z nauki antycznej i koncepcji makro- oraz mikrokosmosu, które zakładały wzajemny wpływ ciał niebieskich na organizmy żywe ${ }^{17}$. Człowiek postrzegany jako część przyrody, będący swoistą kopią wszechświata w miniaturze, był określany terminem mundus parvus, mundus brevis czy mundus minor lub zlatynizowaną przez Izydora z Sewilli grecką formułą mikro $k_{o s m o s}{ }^{18}$. Teorie dotyczące łączności ciała i wszechświata funkcjonowały $\mathrm{w}$ nauce także w okresie średniowiecza. Hildegarda $\mathrm{z}$ Bingen w Liber diviniorum operum przyrównywała elementy ciała człowieka do części kosmosu, wykazując ich łączność ${ }^{19}$. W czasach nowożytnych wiedza ta należała do kanonu dobrego wykształcenia, a przedstawienia i opisy człowieka zodiakalnego - wskazujące na powiązanie zjawisk astralnych oraz 12 konstelacji z najważniejszymi narządami i funkcjonowaniem w ciele humorów - stanowiły częsty element ówczesnych zielników, receptariuszy i poradników dobrego zdrowia ${ }^{20}$. Zarówno w źródłach pamiętnikarskich, jak i w porad-

16 M. Gadocha, Sztuka zielarska w kalendarzach epoki staropolskiej, w: Leki roślinne $w$ terapii od czasów starożytnych po wspótczesne. Zagadnienia teoretyczne i praktyczne, red. B. Płonka-Syroka, A. Syroka, K. Sudoł, Wrocław 2013, s. 113.

17 Nieco podobnie, jak w założeniach trzeciej zasady dynamiki Izaaka Newtona, ciało ludzkie miało odzwierciedlać procesy i zmiany zachodzące w kosmosie, a kosmos miał pozostawać odbiciem ciała człowieka.

18 Z. Kalemba, Wptyw koncepcji makro- $i$ mikrokosmosu na pojmowanie choroby $i$ cztowieka chorego, „Medycyna Nowożytna. Studia nad historią medycyny” 1998, t. 5, z. 1, s. 29-30.

19 J. Jagla, Boska medycyna i niebiescy uzdrowiciele wobec kalectwa i chorób cztowieka, Warszawa 2004, s. 35.

20 M. Gajewska, Epidemia dżumy w Rzeczpospolitej w świetle XVI-XVII-wiecznych traktatów medycznych $i$ zielników. Profilaktyka indywidualna, w: Wśród córek eskulapa. Szkice z dziejów medycyny i higieny w Rzeczpospolitej XVI-XVIII wieku, red. A. Karpiński, Warszawa 2009, s. 16; P. Kowalski, Theatrum świata wszystkiego i poćciwy gospodarz. O wizji świata pewnego siedemnastowiecznego pisarza ziemiańskiego, Kraków 2000, s. 288-290. 
nikach medycznych można spotkać wzmianki wskazujące na wagę i znaczenie, jakie przypisywano wpływowi ciał niebieskich na funkcjonowanie organizmu. Niektóre opisy leczenia obwarowano wskazówkami odnośnie do fazy Księżyca, w jakiej kuracja powinna być stosowana ${ }^{21}$, czy zależności przebiegu choroby od pełni ${ }^{22}$. Staropolskie kalendarze posiłkowały się zaleceniami astrologicznymi - zarówno w przypadku formułowania wskazówek gospodarskich, całorocznych prognoz pogody, jak i zaleceń prozdrowotnych ${ }^{23}$. Wiadomości na temat powiązań Księżyca i ciał niebieskich ze stanem zdrowia i przebiegiem życia człowieka stanowiły immanentną część dawnej nauki i były przedmiotem studiów uczonych ${ }^{24}$. Nowożytne podręczniki, poradniki medyczne, receptariusze, a także kalendarze zawierają wiele informacji na temat wpływu zjawisk astralnych i uwarunkowań astrologicznych na potencjał leczniczy roślin oraz ich wegetację $e^{25}$. Współczesna medycyna traktuje takie porady jako przejaw myślenia magicznego. Tym samym występowanie tego rodzaju zaleceń w kalendarzach i poradnikach medycznych w epoce nowożytnej miałoby stanowić kompromitujący dowód na ich nienaukowy i zabobonny charakter. Należy jednak mieć na uwadze, że astrologia do XVIII w. była dyscypliną naukową, a poglądy na temat wpływu ciał niebieskich na zdrowie człowieka i działanie lecznicze roślin nie miały nic wspólnego z magią, opierały się bowiem na ówczesnym stanie wiedzy i były uznanym faktem. Zawarte w kalendarzach opisy przewidywanych dolegliwości i samopoczucia osób o określonym fenotypie opierały się na hipokratejskiej teorii humoralnej i zakładały wpływ planet na humory, determinujące stan zdrowia, a także samopoczucie i nastrój

21 J. K. Menceliusz, Vade mecum medicum. To iest Apteczka domowa y podróżna, Leszno 1734, s. 21-22.

22 S. W. Jabłonowski, Pamiętnik, Zakład Narodowy im. Ossolińskich, rps 437/II, k. 7v; B. Rudomicz, op. cit., cz. 2, s. 152.

23 Kalendarz polski i ruski na rok panski 1748. [...] przez M. Stanistawa z Eazow Dunczewskiego, [...] wyrachowany, Zamość, k. nlb. 13v-14.

24 Bazyli Rudomicz w pamiętniku wspominał lekturę publikacji astronomicznej „o znaczeniu w życiu nowiu księżyca”; B. Rudomicz, op. cit., cz. 2, s. 328.

25 M. Gadocha, op. cit., s. 117; A. Syroka, Problematyka medyczna w ślaskich kalendarzach z XVII i XVIII wieku, „Medycyna Nowożytna. Studia nad historią medycyny” 1995 , t. 2, z. 1, s. 50-51. 
człowieka. Nie były to magiczne wróżby, a gałąź wiedzy określana jako psychoastrologia ${ }^{26}$, która została negatywnie zweryfikowana w XVIII i XIX w., lecz wcześniej była uznawana za w pełni naukową ${ }^{27}$. Nieuprawnione jest więc przypisywanie zaleceniom opartym na astrologii miana przesądów czy nawet magii, ponieważ była to w omawianym okresie dziedzina nauki - być może niebezpodstawnie usiłująca wskazać na powiązanie stanu organizmu z wpływami wszechświata. Oddziaływanie Księżyca na stan zdrowia człowieka stanowi w ostatnich dekadach przedmiot badań naukowych. Wykazują one, że faza Księżyca ma wpływ na zachowanie człowieka, rozwój jego choroby i proces rekonwalescencji. Zależność ta jest zauważalna i naukowo możliwa do wykazania ${ }^{28}$. Skala zjawiska i jego znaczenie terapeutyczne są dyskutowane i na razie niejednoznaczne. Istotny jest jednak fakt podjęcia na ten temat naukowej debaty.

Podobne podejście, jak w stosunku do astrologii, przejawiają dziś badacze w odniesieniu do dawnych teorii sygnatur i sympatyczności. Nauka na temat wzajemnego powiązania przedmiotów, będących kiedyś w związku lub wykazujących pewne wspólne cechy, zyskała w dzisiejszych czasach status tak dalece metafizyczny, że funkcjonuje już tylko pod nazwą magii

26 A. Syroka, op. cit., s. 52.

27 Poglądy na temat wpływu gwiazd i planet m.in. na wegetację roślin przeżywają w ostatnich latach prawdziwy renesans. Może o tym świadczyć szeroka oferta w kioskach i księgarniach kalendarzy „biodynamicznych”, wskazujących nie tylko dni, ale i godziny przyspieszonej wegetacji określonych gatunków roślin oraz okresy najstosowniejsze do przeprowadzenia zbiorów.

28 Przytaczane badania dotyczą m.in. przypadków wykazanego wpływu fazy Księżyca na zachowania pacjentów leczonych psychiatrycznie, a także przypadków nagłych zawałów i ich powiązania z fazą Księżyca: F. Ahmad et al., A link between lunar phase and medically unexplained stroke symptoms: an unearthly influence?, „Journal of Psychosomatic Research” 2008, vol. 65, no. 2, s. 131-133; W. Burke, J. Leung, D. F. Davey, Lunar and solar influences on human visual disease: the relevance of oedema?, "Biological Rhythm Research” 2012, vol. 43, no. 3, s. 249-266; S. M. R. Kazemi-Bajestani et al., Lunar phase cycle and psychiatric hospital emergency visits, inpatient admissions and aggressive behavior, „Asian Journal of Psychiatry” 2011, vol. 4, no. 1, s. 45-50; W. Stomp, H.-J. Ten Duis, M. W. Nijsten, The impact of the lunar cycle on the incidence of trauma, "Trauma” 2011, vol. 13, no. 2, s. 121-124; C. Z. Turányi et al., Association between lunar phase and sleep characteristics, „Sleep Medicine” 2014, vol. 15, no. 11, s. 1411-1416. 
sympatycznej ${ }^{29}$. Tymczasem idea ta była kiedyś uznawana za prawidło rządzące przyrodą, w niezrozumiały sposób utrzymujące związek między rzeczami, nawet gdy pozostawały one w oddaleniu. Podobnie jak koncepcja zwierzęcego magnetyzmu (stosunkowo szybko negatywnie zweryfikowana przez XVIII-wieczną medycynę), teoria sympatyczności była przez pewien czas dziedziną badań naukowych i pozostawała uznaną gałęzią medycy$n^{30}$. Znany lekarz Antoni Formika, sprzedający w Warszawie swój proszek oczyszczający ciało ze złych jadów i zepsutych humorów, reklamował go jako środek sympatyczny: „[...] szmatkę białą, czystą złożoną w kilkoro, żeby ropę w się brała, którę chusteczki potym w ogień, nie na ziemię rzucać, bo tego doznali niektórzy pacyenci, że czuli ból w ranie, a to tey przyczyny, że iest medykament sympatyczny"31. Teoria sympatyczności pozostawała w pewnym związku z propagowaną m.in. przez Paracelsusa koncepcją sygnatur $^{32}$. Zakładała istnienie stałego związku między chorobami trapiącymi ludzkość a niezawodnymi lekarstwami występującymi naturalnie w przyrodzie. Sztuką wymagającą wiedzy i pogłębionych studiów było odszukanie tych zależności oraz odkrycie skutecznego leku (arcanum). Znakami ułatwiającymi to zadanie były „sygnatury” wskazujące na przydatność danej rośliny na konkretną przypadłość. Rdest wężownik ze względu na swój wydłużony kształt miał stanowić lek chroniący przed skutkami ukąszeń jadowitych zwierząt, melisa lekarska na podstawie kształtu liścia (sercowaty) miała leczyć serce, a charakterystyczny orzech nerkowca uzdrawiać nerki ${ }^{33}$. Powiązania między chorobą a skutecznym lekarstwem nie wynikały z supernaturalistycznego charakteru terapii, lecz stanowiły odzwierciedlenie sposobu postrzegania wszechświata przez ówczesną naukę. Wzajemne wpływy gwiazd i planet na człowieka oraz funkcjonujące w naturze zależności miały

29 P. Kowalski, Leksykon znaki świata. Omen, przesą, znaczenie, Warszawa-Wrocław 1998, s. 296.

30 H. Schott, Der sympathetische Arzt, München 1998, s. 24.

31 A. Formika, Cnoty y używanie proszku puryfikującego albo czyszczącego, który się znajduje w Warszawie u Fizyki Doktora Antoniego Formiki, Warszawa [s.a.], s. 2.

32 F. Lebrun, Jak dawniej leczono. Lekarze, święci i czarodzieje w XVII i XVIII wieku, tłum. Z. Podgórska-Klawe, Warszawa 1997, s. 73-77.

33 H. Vorwahl, Geschichte der Medizin unter Berücksichtigung der Volksmedizin, „Medizinisch-Biologische Schriftenreihe” 1928, Bd. 9, s. 101-102. 
łączyć się z naturalnymi mechanizmami rządzącymi światem, a astrologia czy teoria sygnatur były w tym kontekście nauką wyjaśniającą w rozumowy sposób ich zasady.

Badaczom dawnej medycyny zdarza się też nieraz dostrzegać aspekty naukowości w analizowanych poglądach i metodach terapii, ale interpretują je zgodnie z aktualną we własnych czasach wiedzą, dostrzegając odbłyski „obiektywnej prawdy” w jej niedoskonałej, archaicznej postaci. Zauważając elementy pasujące do obecnego stanu wiedzy, a dotyczące sposobów walki z chorobami, implikują relacjom źródłowym swój sposób myślenia - czasem nawet sugerując, że medycy w przeszłości „intuicyjnie” dążyli do znanych nam dziś skutecznych metod leczenia ${ }^{34}$. Takie przedstawienie przeszłości jest anachroniczne i z założenia błędne. Jeśli nawet niektóre ze stosowanych metod leczenia współcześnie do pewnego stopnia, jak się okazuje, pokrywają się z aktualną wiedzą i zaleceniami medycyny, to efekt ten często jest dziełem przypadku. Nawet w sytuacjach, gdy są podstawy do stwierdzenia, że stosowanie danej metody leczenia - która także obecnie jest pozytywnie oceniana - wynikało z jej obserwowanej obiektywnej skuteczności, mechanizm tłumaczenia jej działania był zupełnie inny. Nie należy ulegać pokusie przypisywania źródłom historycznym dzisiejszej racjonalności, ponieważ prowadzi to do zafałszowania obrazu przeszłości. Gdy Jan Chryzostom Pasek doświadczył w Danii sztormu, przemoczony i zziębnięty udał się do gospody, o czym zanotował: „[...] dał mi gospodarz koszulę suchą; uczyniono ciepło w izbie - rozpaliwszy [...], kazałem spory garniec miodu [do ognia] wstawić (bo tam wina złe), nasypałem gwoździków, imbieru, tom tak pił. [...] ja u ognia w koszuli siedzę a zagrzewam się owym miodem" ${ }^{35}$. Z punktu widzenia aktualnej wiedzy medycznej leczenie przeziębienia takim sposobem wydaje się uzasadnione. Zawarty w goździkach eugenol wykazuje działanie przeciwdrobnoustrojowe oraz przeciwzapalne, zaś związki aktywne zawarte w imbirze także działają przeciwzapalnie ${ }^{36}$. Być może Pasek stosował opisaną terapię, ponieważ zauważył wcześniej jej pozytywne efekty. $\mathrm{Z}$ pewnością jednak zupełnie inaczej tłumaczył zasady jej ewentualnej

\footnotetext{
34 Por. J. Węglorz, Wspótpraca interdyscyplinarna..., s. 243-245.

5 J. Ch. Pasek, Pamiętniki, oprac. W. Czapliński, Wrocław 2003, s. 55.

36 S. Kohlmünzer, Farmakognozja, Cieszyn 1998, s. 223, 589.
} 
skuteczności. Przeziębienie wynikające z przemoczenia i wychłodzenia było spowodowane przez skumulowanie się w organizmie wilgotnych i zimnych humorów prowadzących do powstania procesu chorobowego. Aby je wyeliminować, należało stosować środki rozgrzewające humory i je wypalające. Zaliczały się do nich alkohol oraz przyprawy o ostrym i piekącym smaku. Sięgając po wino z goździkami i imbirem, Pasek działał zgodnie z ówczesną racjonalnością i zasadami wskazywanymi przez obowiązującą wówczas doktrynę medyczną. Mylące dla dzisiejszego badacza może być też zalecenie szczególnej troski w okresie epidemii nad melancholikami, którzy mieli być bardziej podatni na zachorowanie. Według aktualnej wiedzy o psychologii człowieka stan emocjonalny ma wpływ na zdolność organizmu do obrony przed chorobą, a melancholia interpretowana często (i nie do końca słusznie) jako depresja miałaby negatywnie rzutować na odporność. Trudno jednoznacznie odpowiedzieć, czy w istocie zależność taka występowała i czy rzeczywiście melancholicy częściej zapadali na choroby zakaźne. Z pewnością jednak ważnym czynnikiem nakazującym wzmożoną troskę o nich były ówczesne poglądy medyczne. Wedle założeń doktryny humoralnej dominacja czarnej żółci, niwecząc radość życia, jednocześnie przyciągała do siebie znajdujące się w powietrzu trucizny odpowiedzialne za rozprzestrzenianie się moru ${ }^{37}$. Troski i złe samopoczucie miały być zresztą niebezpieczne także w czasach wolnych od zarazy, długie utrzymywanie się frasunku mogło ściagnąć na człowieka inne choroby, a nawet śmierć. Pogląd ten był bardzo rozpowszechniony i znajduje odzwierciedlenie w staropolskich źródłach: „miecznik koronny Jabłonowski [...] ze smutku, spowodowanego przyjęciem przez posłów jego słów i wotum sejmowego, chociaż nic mu nie dolegało, zmarł ku wielkiemu żalowi zacnych ludzi” ${ }^{38}$, „co ja ucierpiałem i co miałem gryzoty, mogę mówić, że mnie to na dziesięć lat wieku ukrócito" ${ }^{39}$, „nieuspokoiłem się, owszem zachorowałem z tej zgryzoty”40, „umarła

37 P. Kowalski, Theatrum świata..., s. 309.

38 A. S. Radziwiłt, Pamiętnik o dziejach w Polsce. Tom 3 1647-1656, tłum. i oprac. A. Przyboś, R. Żelewski, Warszawa 1980, s. 35.

39 J. J. Przebendowski, Listy Jana Jerzego Przebendowskiego podskarbiego wielkiego koronnego do Jana Szembeka podkanclerzego i kanclerza wielkiego koronnego z lat 1711-1728, oprac. A. Perłakowski, Kraków 2010, s. 43.

40 S. W. Jabłonowski, op. cit., rps 437/II, k. 8. 
Królowa polska Maryja Ludwika, długo chorując, ale osobliwie ex maerore [ze smutku]” "41, „są takie przypadki, w których ułożenia duszy, bywaią walnemi przyczynami odmian w ciele” ${ }^{2}$. Postępowanie autorów źródeł, nawet gdy bywało zgodne z zaleceniami dzisiejszej medycyny, wynikało z założeń dominującej wówczas patologii humoralnej i tak też powinno być przedstawiane i interpretowane.

Stosowanie dzisiejszej racjonalności i perspektywy naukowej w odniesieniu do wykorzystywanych w epoce nowożytnej działań terapeutycznych jest częstą praktyką, mającą na celu ułatwienie badaczowi zrozumienia celu podejmowania irracjonalnych (z perspektywy podmiotu poznającego) działań. W literaturze przedmiotu można spotkać wiele różnych wyjaśnień wskazujących na potencjalną zasadność działań, takich jak np. usuwanie cmentarzy poza obręby murów miejskich, iniekcja dożylna leków nowożytnych czy bicie $\mathrm{w}$ dzwony i strzelanie $\mathrm{z}$ armat $\mathrm{w}$ czasie epidemii ${ }^{43}$. Niektóre z nich rzeczywiście mogą wykazywać pewne szanse na poprawę stanu zdrowia czy warunków sanitarnych, efekt innych pozostaje marginalny lub nawet szkodliwy. Co istotne jednak, działania te były podejmowane najczęściej nie ze względu na „intuicyjne” dążenie do racjonalnych (w rozumieniu XXI w.) metod leczenia, lecz z założeń ówczesnej doktryny medycznej. Wyławianie z morza różnych koncepcji i działań pojedynczych przykładów, które zgadzają się z naszym oglądem świata, i stawianie ich w opozycji do reszty ówczesnej wiedzy medycznej jest błędem zaciemniającym obraz przeszłości. W przeważającej większości zalecenia lecznicze propagowane przez nowożytną medycynę oficjalną pozostają w zgodzie z ówczesną nauką i racjonalnością epoki. Próby ich oceny z perspektywy obecnego stanu wiedzy powinny ograniczać się do analizy ewentualnej skuteczności czy też zasadności podejmowanych działań - niezależnie o tego, czy dziś ocenialibyśmy je jako racjonalne, czy też nie.

41 J. A. Chrapowicki, Diariusz. Część druga: lata 1665-1669, Warszawa 1988, s. 318.

42 Przepisy dyetetyczne czyli reguty zachowania się $w$ czerstwym zdrowiu y przedtużenia życia, Warszawa 1785, k. nlb. 9-9v.

43 Zob. J. Węglorz, Wspótpraca interdyscyplinarna..., s. 225-248. 